\title{
A COVID-19 járvány hatása a közösségi terek használatára és jövőjére
}

\author{
Impacts of the COVID-19 epidemic on the use and future \\ of public spaces
}

\author{
JÓNA LÁSZLÓ
}

\begin{abstract}
JÓNA László: tudományos munkatárs, Közgazdaság- és Regionális Tudományi Kutatóközpont, Regionális Kutatások Intézete, Nyugat-magyarországi Tudományos Osztály; 9022 Győr, Liszt Ferenc utca 10.; jonal@rkk.hu; Széchenyi István Egyetem, Közlekedési Tanszék; 9026 Győr, Egyetem tér 1.; jona.laszlo@sze.hu; https://orcid.org/0000-00019052-9589
\end{abstract}

KULCSSZAVAK: közösségi tér; tér; park; COVID-19; felmérés; lakosság

László JÓNA: research fellow, West-Hungarian Research Department, Institute for Regional Studies, Centre for Economic and Regional Studies; Liszt Ferenc utca 10., H- 9022 Györ, Hungary; jonal@rkk.hu; Department of Transport, Széchenyi István University; Egyetem tér 1., H-9026 Győr, Hungary; jona.laszlo@sze.hu; https://orcid.org/0000-0001-9052-9589

KEYWORDS: public space; square; park; COVID-19; survey; inhabitants

\section{Bevezetés}

A COVID-19 (koronavírus) járvány kitörése az élet minden területére hatással volt, így a közösségi terek használatára is. A városi köztereket és parkokat a vírus hazai megjelenésétől kezdve egyre kevesebben kezdték látogatni, amit aztán a kormány márciusi rendeletében hivatalosan is korlátozott. A 71/2020. (III. 27.) Korm. rendelet 5. §-a a kijárási korlátozásról ugyanis kimondta, hogy „Egyéni szabadidős sporttevékenység, szabadidős célú gyalogos közlekedés külterületen, valamint a települések belterületén - lehetőség szerint a zöldterületeken - egyedül vagy ugyanazon háztartásban élőkkel közösen folytatható azzal, hogy másoktól legalább 1,5 méter távolságot kell tartani." Ezt követően a legtöbb településen a helyi önkormányzatok lezárták a köztereket és parkokat a lakosság előtt, hogy ezzel is meggátolják a koronavírus-járvány tömeges terjedését. Ugyanakkor a tapasztalatok és a hírek szerint a legtöbb településen sokan a korlátozások ellenére is aktívan használták a helyi közösségi tereket. Arról is lehetett hallani, hogy más városrészekből vagy településekről mentek át családok az adott parkba vagy térre kikapcsolódni, szórakozni.

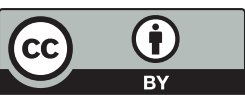


A kutatásom célja egyrészt annak feltárása volt, hogyan változott meg a COVID-19 járvány kitörése óta a közösségi terek használata hazánkban. Másrészt arra kerestem a választ, hogy a járvány elmúltával hogyan lehet újra vonzóvá tenni a köztereket és parkokat azok számára, akik a koronavírus miatt egyáltalán nem látogatták azokat. Hazai és nemzetközi kutatások igazolták ugyanis, hogy a közösségi terek, különösen a városokban és nagyvárosokban, jelentős szerepet játszanak abban, hogy a települések élhetőek legyenek a helyi lakosság számára (Madden 2008; Thompson 2002). Nem véletlen, hogy ezt felismerve, sok nyugateurópai országban komoly közterület-fejlesztési programba kezdtek, ami az esetek többségében zöldterület-fejlesztéssel is járt (Ghel 2014). A zöldterületek ugyanis a terekhez és parkokhoz hasonlóan, befolyásolják az adott település élhető voltát és fenntarthatóságát (Anguluri, Narayanan 2017).

A felmerés során így a hazai közterek és parkok használatának megváltozása mellett azt is feltártam, hogy mi az, amit a lakosság szívesen látna ezeken a tereken. Milyen eszközökkel, utcabútorokkal rendelkezzenek, és mennyire fontos a zöldterületek nagysága.

\section{Az online felmérés kitöltőinek háttere}

A lakossági online felmérés 2020. április 26-tól május 16-ig tartott, összesen 287-en kezdték meg a kérdőív kitöltését, melyet végül 170-en fejeztek be, így a jelenlegi feldolgozásba csak a teljesen befejezett 170 kérdőív került bele. A kitöltések alacsony száma miatt, és mivel a felmérésben elsősorban a Győr-Moson-Sopron megyében élők vettek részt (53\%), a kutatás eredménye nem reprezentatív és megállapításai nem általánosíthatóak. Ugyanakkor a kapott válaszok hasznos információval szolgálnak arról, hogyan változtatta meg a lakosság egy részének viszonyát a közösségi terekhez a koronavírus-járvány.

A válaszadók között $50 \%$ volt nő, $32 \%$ férfi, $18 \%$ nem válaszolt erre a kérdésre. A legtöbben a 30 és 40 év (42\%) közötti korosztályból töltötték ki a kérdőívet, őket követték a 41 és 50 év közöttiek (19\%). A többi korcsoport 15\% alatti arányban képviselte magát a felmérésen, de a 20 évesnél fiatalabb korosztály figyelmét nem keltette fel a kutatás, mindössze egy válasz érkezett e korcsoportokból. Esetükben az lett volna célravezető, ha az iskolákon keresztül keresem meg őket, ehhez azonban hosszabb kutatási időre lett volna szükség. A válaszadók majdnem fele (46\%) egyetemi (MA, MSc) végzettséggel rendelkezett, közel negyede (24\%) pedig főiskolaival (BA, BSc). Érettségivel a kérdőív kitöltöinek 20\%-a, szakmunkás, illetve szakiskolai képesítéssel pedig a 4\%-a. Az egyéb kategóriát összesen 9 fö (5\%) jelölte be, ők szinte kivétel nélkül a doktori fokozatról (PhD) tettek említést.

A kérdőív kitöltőinek valamivel több, mint a fele (52,9\%) megyeszékhelyen lakott, 20\% városban, 15,3\% községben és 11,2\% volt fővárosi lakos. A kérdőívet a 
Győr-Moson-Sopron megyében élők töltötték ki a legnagyobb arányban (52,9\%), Budapest 11,2\%-ot képviselt, a többi megyéből 10\% alatti volt a kitöltések aránya. Nógrád, Tolna, Bács-Kiskun, és Heves megyéből egyáltalán nem érkezett válasz.

\section{A közösségi terek használata a COVID-19 járvány kitörése előtt}

A kapott válaszokból egyértelműen kiderült, hogy a legtöbben (77\%) legfeljebb 10 percre laknak attól a parktól vagy tértől, amit a leggyakrabban látogatnak. Ezen belül is elsősorban kevesebb, mint 5 percnyire 37\%, 5 percnyire 19\%, 6-10 percnyire pedig $21 \%$. A 11 és 15 percnyi távolságot mindössze $11 \%$ jelölte meg, a 16-20 percnyit pedig csak 6\%. A 21 percnél nagyobb távolságot a válaszadók 5\%-a jelölte meg (1.ábra). Mindez megerősítette a korábbi kutatásokat, mely szerint az emberek elsősorban a lakóhelyükhöz legközelebbi közösségi teret látogatják szívesen (Jóna 2016).

1. ábra: A leggyakrabban látogatott közösségi tér időbeli elérhetősége Time availability of the most visited public space

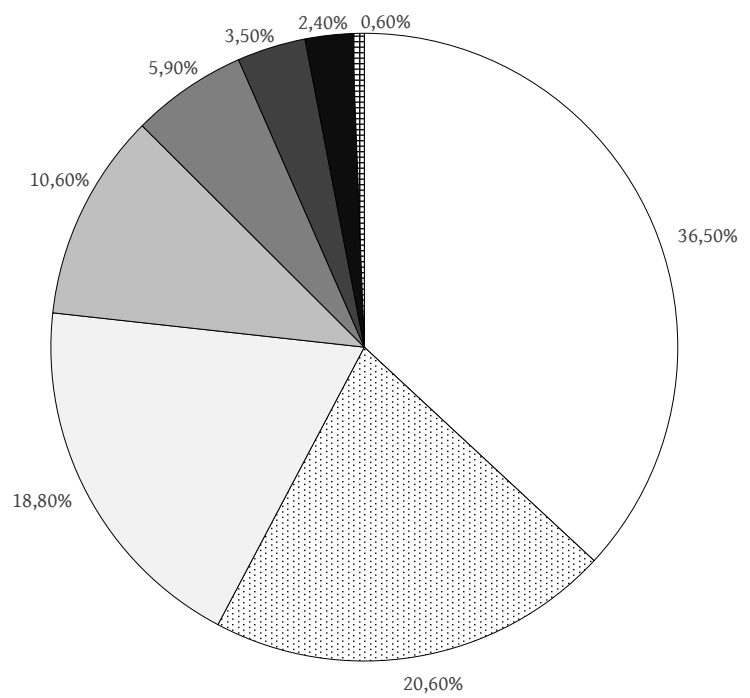

$\square$ Kevesebb, mint 5 percnyire $:$ 6-10 percnyire

$\square$ 16-20 percnyire

Forrás: saját szerkesztés

A járvány kitörése előtti időszakban a válaszadók több mint negyede (30\%) hetente többször meglátogatta a hozzá legközelebbi teret vagy parkot (2. ábra). Naponta 12\%, heti rendszerességgel 19\% kereste fel kedvenc közösségi terét. Fontos azonban rámutatni, hogy a kérdőív kitöltőinek 22\%-a egy hónapnál ritkábban 
2. ábra: A közösségi terek terek látogatottságának gyakorisága The visit frequency of the public spaces

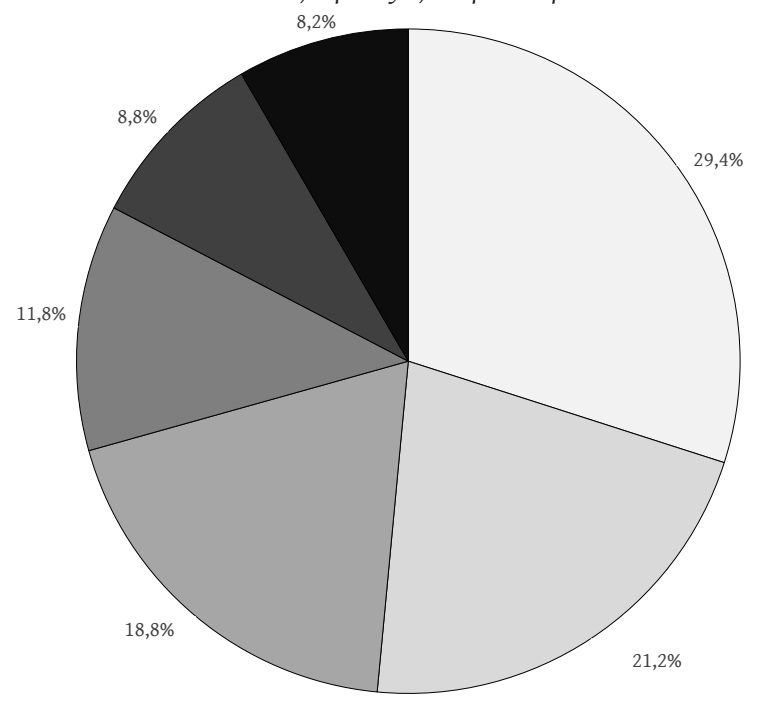

\section{Forrás: saját szerkesztés}

$\square$ Hetente többször $\square$ Egy hónapnál ritkábban $\square$ Hetente $\square$ Naponta $\square$ Kéthetente

Havonta

3. ábra: A terek és parkok használati célja a koronavírus-járvány előtt The purpose of use of squares and parks before the coronavirus epidemic

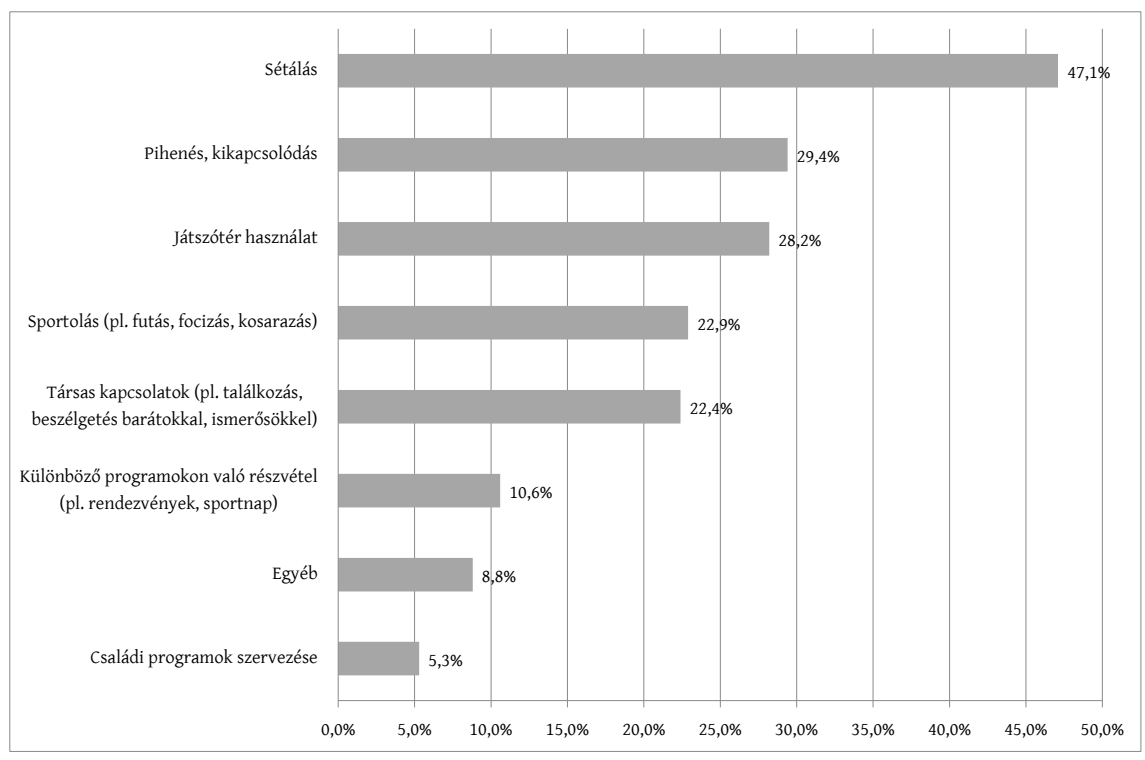

Forrás: saját szerkesztés 
mozdult ki ilyen céllal. A kétheti (9\%) és havi (8\%) látogatottság aránya pedig még a 10\%-ot sem érte el.

Arra a kérdésre, hogy milyen céllal vették igénybe a kérdőív kitöltői az általuk leggyakrabban látogatott teret vagy parkot, a legtöbben a sétálást $(47,1 \%)$ jelölték meg, amit a pihenés, kikapcsolódás követett (29,4\%) (3.ábra). A játszótér használat $(28,2 \%)$ a harmadik legtöbb jelölést kapta, és holtversenybe került a sportolás (pl. futás, focizás, kosarazás) (22,9\%), valamint a társas kapcsolatok (pl. találkozás, beszélgetés barátokkal, ismerősökkel) (22,4\%). A különböző programokon való részvételt (pl. rendezvények, sportnap) valamivel több, mint 10\% jelölte meg, a családi programok szervezését pedig mindössze 5,3\%. Az egyéb kategóriát $8,8 \%$ választotta ki; többen arról számoltak be, hogy kutyasétáltatás céljából keresték fel a közeli közösségi teret. Sokan írták azt is, hogy csak áthaladtak rajta, illetve hogy semmilyen céllal nem keresték fel.

\section{A közösségi terek használata a COVID-19 járvány kitörése óta}

Felmérésem egyik legfontosabb célja annak feltárása volt, hogy a koronavírusjárvány kitörése, és a bevezetett korlátozások milyen módon befolyásolták a közösségi terek látogatási kedvét. A kapott válaszokból egyértelműen kiderült, hogy a kérdőív kitöltőinek 54\%-a a vírus megjelenésétől kezdve nem látogatta kedvenc terét vagy parkját, 46\%-a azonban különböző gyakorisággal ugyan, de továbbra is felkereste azt (4. ábra). Ezen belül 14\% hetente többször, $11 \%$ hetente, $6 \%$ naponta, $5 \%$ kéthetente, $2 \%$ havonta, és mindössze $8 \%$ nyilatkozott úgy hogy egy hónapnál ritkábban.

Akik az előző kérdésben úgy nyilatkoztak, hogy továbbra is felkeresték a hozzájuk legközelebbi teret vagy parkot (46\%), elsősorban sétálás céljából tették (29,4\%) (5. ábra). Ezt követte a sportolás (pl. futás, focizás, kosarazás) (11,8\%), majd kis különbséggel a pihenés, kikapcsolódás (10,6\%). A további szempontok közül az egyéb (5,9\%) kategórián kívül egyik sem érte el még a 2\%-ot sem. A leglátványosabb visszaesésről a játszótér használata $(1,2 \%)$, a társas kapcsolatok (pl. találkozás, beszélgetés barátokkal, ismerősökkel) $(1,8 \%)$ és a különböző programokon való részvétel (pl. rendezvények, sportnap) (0\%) esetében számoltak be. Ebben természetesen jelentős szerepet játszott a tömegrendezvények betiltása, a csoportos tevékenységek korlátozása, illetve a vírustól való félelem. Az egyéb kategóriába többen azt írták, hogy „nem veszik igénybe” a közösségi tereket, valamint hogy csak áthaladnak rajtuk. Ezen kívül azonban megjelent a kutyasétáltatás, a munka és a kerékpározás.

Arra a kérdésre, hogy a válaszadók összeségében hogyan ítélik meg kedvenc közösségi terük látogatottságának változását, $55 \%$ válaszolta azt, hogy egyáltalán nem látogat oda a koronavírus-járvány kitörése óta. Mindössze 14\% keresi fel ugyanúgy, mint korábban, $13 \%$ ritkábban, $8 \%$ pedig gyakrabban. A két szélsőséget 
4. ábra: A terek és parkok látogatottsága a koronavírus-járvány kitörése után The visitors rate of the squares and parks after the coronavirus pandemic outbreak

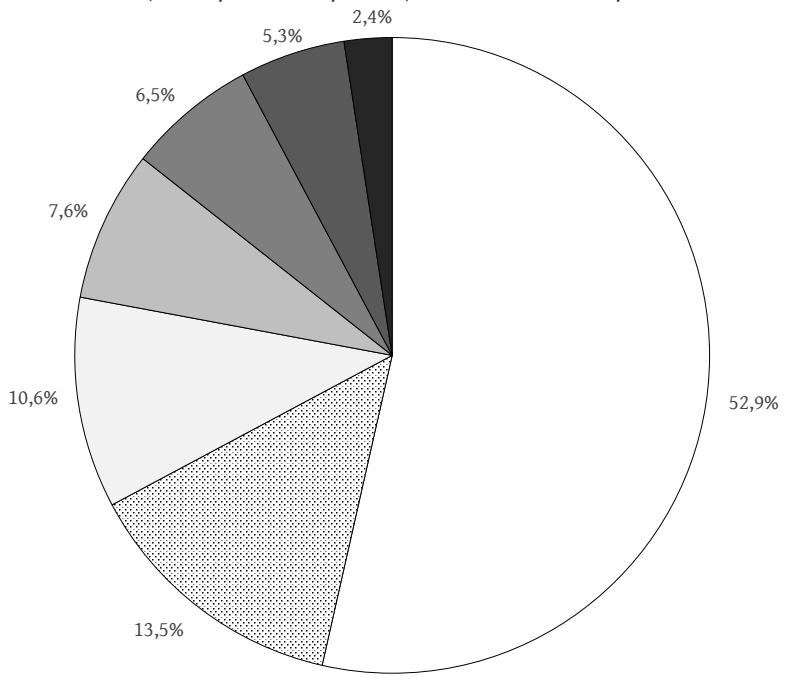

$\square$ A járvány kitörése óta 웅 Hetente többször $\square$ Hetente $\square$ Egy hónapnál ritkábban

Naponta Kéthetente nem jártam ott

\section{Forrás: saját szerkesztés}

5. ábra: A terek és parkok használati célja a koronavírus-járvány kitörése után The purpose of use of squares and parks after the coronavirus pandemic outbreak

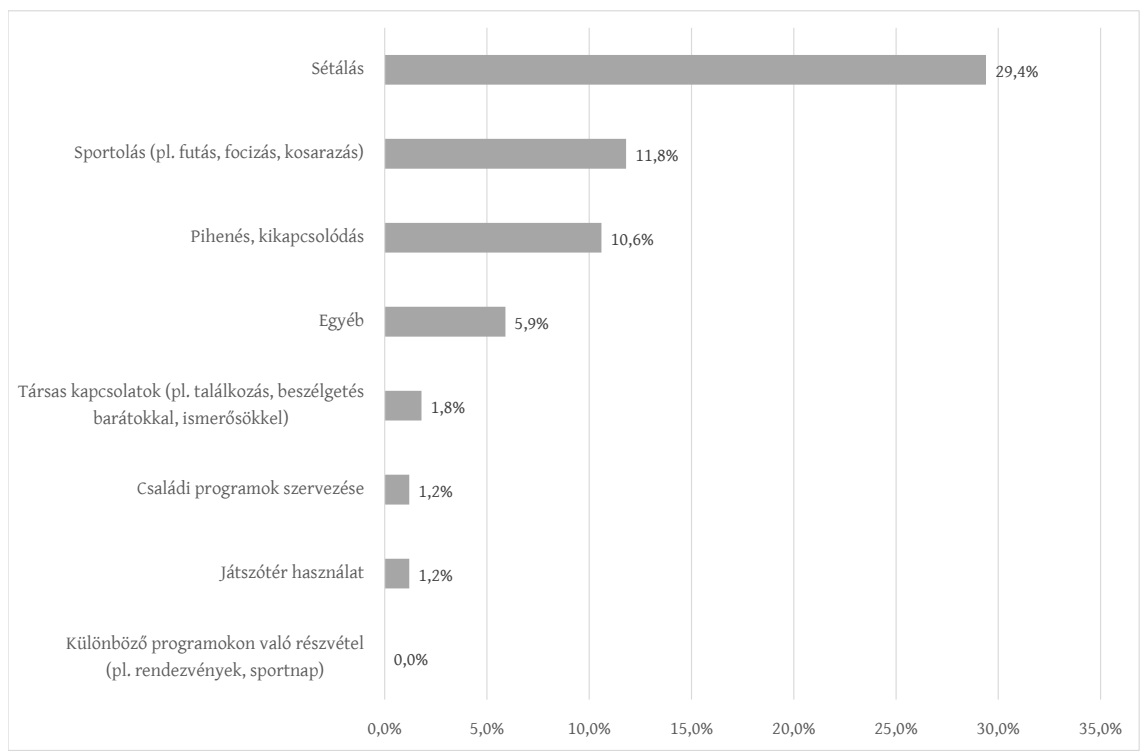

Forrás: saját szerkesztés 
tekintve egyaránt $5 \%$ nyilatkozta azt, hogy nagyon ritkán, illetve sokkal gyakrabban felkeresi a közeli teret, vagy parkot (6. ábra).

A következő kérdésben indoklásra kértem azokat, akik gyakrabban látogatják a közeli tereket, vagy parkokat. Nagyon eltérő válaszok születtek, de összességében elmondható, hogy az emberek döntően mozgásigényük napi kielégítése miatt tettek így. Többen írták ugyanis, hogy mivel a vírusveszély miatt szinte minden bezárt, csak a parkok és terek biztosítottak számukra sportolási és mozgási lehetőséget. Néhányan azt is megemlítették, hogy az otthoni munkavégzés időszaka alatt lett több szabadidejük arra, hogy gyakrabban kimozduljanak otthonról. Azok viszont, akik ritkábban, vagy egyáltalán nem keresték fel a közeli parkokat, tereket, elsősorban két fó okot említettek meg: a kijárási korlátozást és a koronavírustól való félelmet. A többség egyértelműen eleget tett a „maradj otthon” felhívásnak, de néhányan megemlítették azt is, hogy azért tudtak otthon maradni, mert rendelkeznek saját kerttel. Néhányan a játszóterek lezárására hivatkozva nem keresték fel a közeli parkokat.

6. ábra: A terek és parkok látogatottságának megváltozása a járvány kitörése után The visitors rate change of the squares and parks after the coronavirus pandemic outbreak
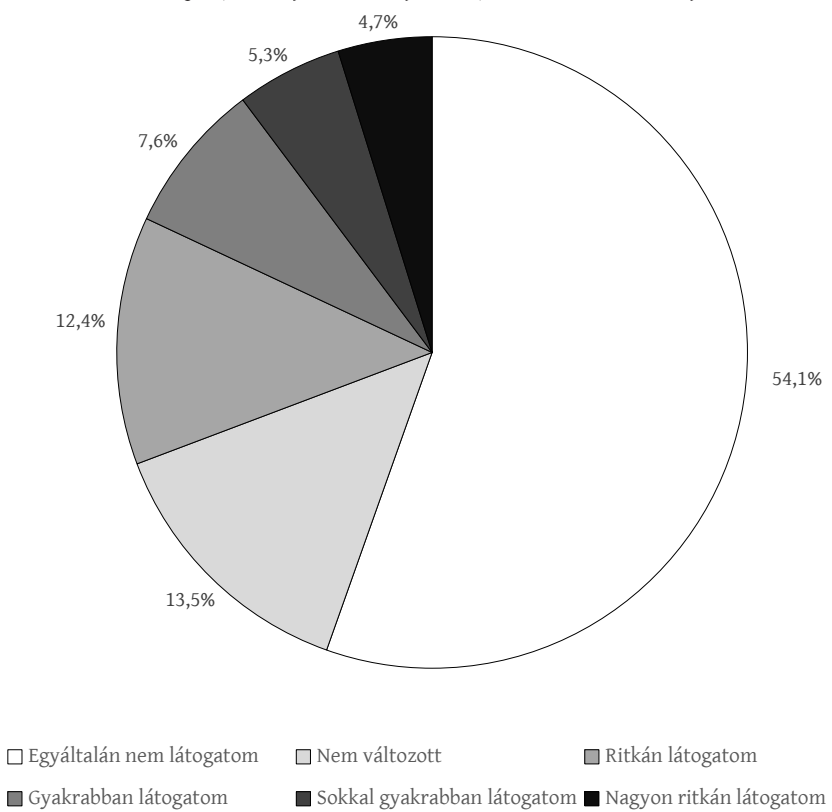

Forrás: saját szerkesztés

\section{A közösségi terek használata a COVID-19 járvány után}

A felmérés befejező része arra kereste a választ, hogy a koronavírus-járvány elmúlását követően hogyan használják majd az emberek a közösségi tereket. 
Így elsőként arra kellett választ adniuk a kérdőív kitöltőinek, hogy mit gondolnak, milyen hamar fogják újra meglátogatni a hozzájuk legközelebb található teret vagy parkot. A kapott válaszokból érdekes kettőség látszik, ugyanis 36\% már egy héttel a vírusveszély elmúlását követően újra birtokba szeretné venni kedvenc közösségi terét, míg $25 \%$ inkább várna még egy hónapot. A válaszadók 12\%-a két hetet, $13 \%$-a pedig három hónapot várna, a fél évet $7 \%$ jelölte meg, egy év várakozást mindössze $2 \%$. Érdekes módon azonban voltak olyanok is (5\%), akik úgy gondolják, egy évnél hosszabb idő kell számukra ahhoz, hogy ismét biztonsággal sétálhassanak a kedvenc terükön vagy parkjukban (7. ábra).

Arra a kérdésre, hogy a járvány elmúltával hogyan változik majd a közösségi terek látogatásának gyakorisága, a válaszadók több mint fele (58\%) úgy nyilatkozott, hogy ugyanannyiszor fogja látogatni, mint korábban (8. ábra). Valamivel kevesebb, mint a negyedük (22\%) gyakrabban, ezen belül is $8 \%$ sokkal gyakrabban, míg 17\% fogja a korábbinál ritkábban, s ezen belül $4 \%$ válaszolta azt, hogy nagyon ritkán keresi majd fel a hozzá közeli parkot vagy teret. Mindössze 3\% gondolta úgy, hogy egyáltalán nem fogja többé látogatni a hozzá közeli közösségi teret.

A következő kérdésben azoknak, akik azt tervezik, hogy a járvány elmúlását követően gyakrabban járnak majd a közösségi terekre, meg kellett indokolniuk a

7. ábra: A közösségi terek újra felkeresésének ideje a koronavírus-járvány elmúlását követően The revisit of public spaces after the passing of the coronavirus pandemic

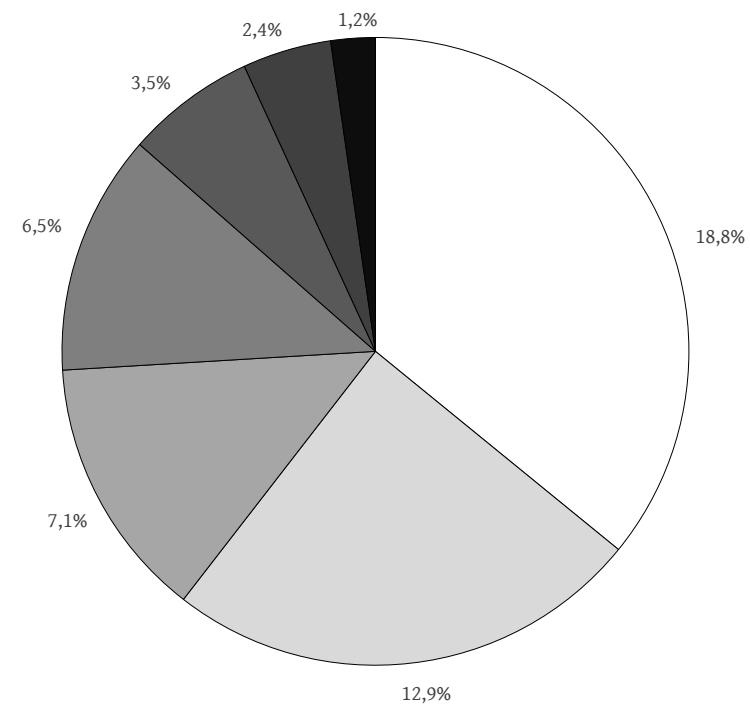

$\square$ Egy hét múlva

$\square$ Egy hónap múlva

$\square$ Három hónap múlva

$\square$ Két hét múlva

$\square$ Fél év múlva

—Egy évnél hosszabb idő után

Egy év múlva 
8. ábra: A terek és parkok látogatottságnak megváltozása a járvány elmúlását követően The visitors rate change of the squares and parks after the passing of the coronavirus epidemic

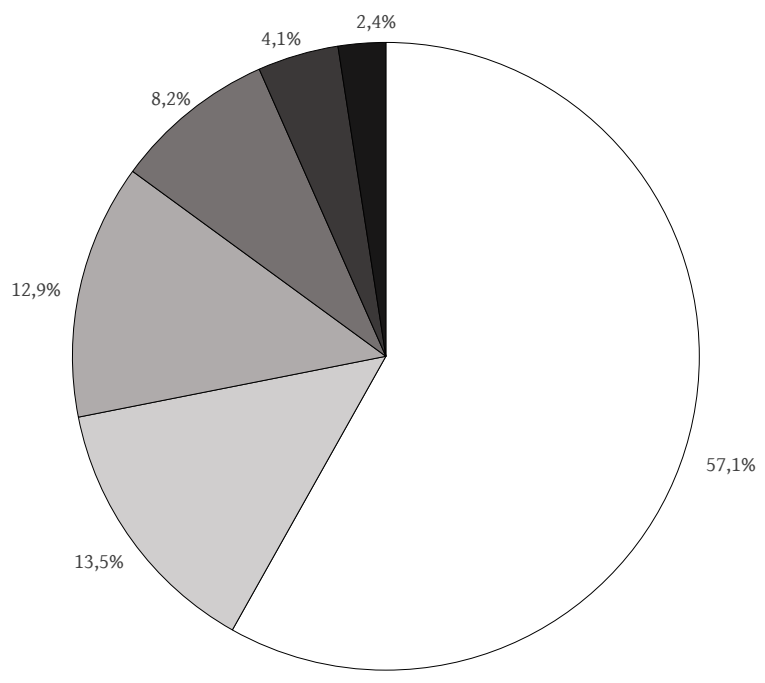

$\begin{array}{ll}\square \text { Ugyanannyiszor fogom látogatni } \quad \square \text { Gyakrabban fogom látogatom } & \square \text { Ritkábban fogom látogatni } \\ \square \text { Sokkal gyakrabban fogom látogatni } \square \text { Nagyon ritkán fogom látogatni } & \square \text { Egyáltalán nem fogom látogatni }\end{array}$

Forrás: saját szerkesztés

válaszukat. Ez alapján három csoportot lehetett elkülöníteni: a családosok azt írták, hogy a gyerekeiket szeretnék újra kedvenc játszóterükre vinni, és ha lehet gyakrabban, mint korábban; mások a vírusveszély elmúltával szeretnének minél több időt tölteni a szabadban, elsősorban a közeli parkokban vagy zöldterületen; s vannak, akik a társas kapcsolatok hiánya miatt szeretnék minél gyakrabban felkeresni a közeli parkokat és tereket.

Azok között, akik úgy gondolják, hogy ritkábban fogják látogatni a hozzájuk közeli közösségi tereket, szintén három csoportot lehetett megkülönböztetni: vannak, akik a koronavírustól való félelem miatt; vannak, akik a járvány után inkább más helyeket szeretnének (újra) felkeresni, melyek az elmúlt hónapokban zárva voltak (pl. edzőtermek); mások pedig azért fogják ritkábban látogatni a tereket és a parkokat, mert az otthoni munkavégzés megszűnésével kevesebb időt tudnak majd a szabadban tölteni.

Az online felmérés utolsó blokkjában választ kellett adniuk a kérdőív kitöltőinek arra a kérdésre is, hogy a koronavírus-járvány elmúlása után elsősorban milyen céllal fogják igénybe venni a hozzájuk legközelebb található tereket és parkokat. A járvány kitörése előtti időszakra vonatkozó válaszokkal (3. ábra) összehasonlítva, továbbra is a séta a legépszerủbb tevékenység (9. ábra), de a sportolást (pl. futás, focizás, kosarazás) (28,2\%) 6\%-al többen jelölték meg, mint korábban. Így a járvány elmúltával többen tervezik a sportolást a közösségi tereken, illetve a társas kapcso- 
9. ábra: A terek és parkok használati célja a koronavírus-járvány elmúlását követően The purpose of use of squares and parks after the passing of the coronavirus pandemic

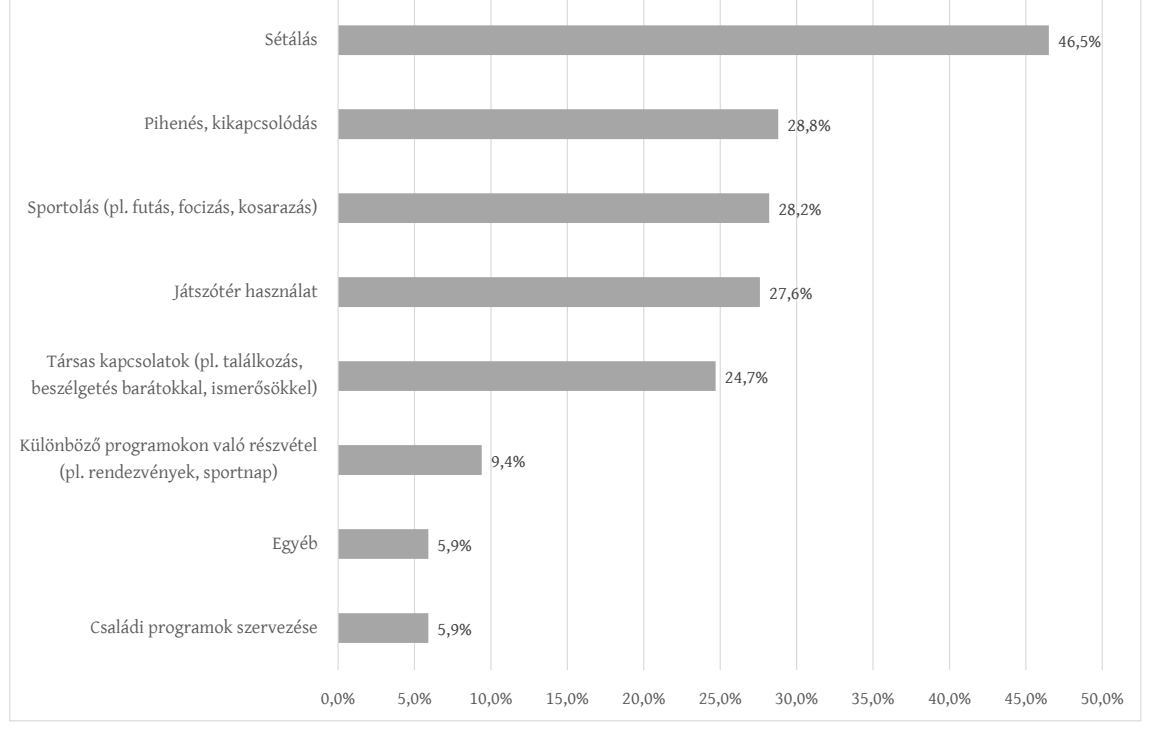

Forrás: saját szerkesztés

latok ápolása (pl. találkozás, beszélgetés barátokkal, ismerősökkel) $(24,7 \%)$ is enyhe növekedést mutatott, a pihenés, kikapcsolódás $(28,8 \%)$ a játszótér használat (27,6\%), és a különböző programokon való részvétel (pl. rendezvények, sportnap) pedig enyhe csökkenést. Az egyéb kategóriát (5,9\%) szintén kevesebben választották; továbbra is a kutyasétáltatást, és a területen történő áthaladást írták a legtöbben.

A felmérés utolsó előtti kérdésében arra kellett szöveges választ adniuk a kérdőív kitöltőinek, hogy véleményük szerint a koronavírus-járvány után mivel lehetne újra vonzóvá tenni a tereket és a parkokat ahhoz, hogy ugyanannyira népszerüek legyenek, mint korábban. A válaszadók egy jelentős része úgy gondolta, hogy semmilyen intézkedésre nem lesz szükség, mert a terek és parkok a vírusjárvány elmúlását követően ugyanolyan népszerűek lesznek, mint azelőtt. Néhányan azt is kiemelték, hogy a tiltás feloldásával valószínüleg még többen lesznek a közösségi tereken, mint korábban, mert a korlátozások idején sehová nem tudtak menni az emberek. A válaszadók másik része azonban úgy vélte, a terek és parkok rendszeres karbantartása, tisztítása, a növényzet gondozása, a megfelelő számú szemetes kihelyezése segíthet abban a legtöbbet, hogy újra népszerüek legyenek. A több növényzetet és a zöldterület növelését nagyon sokan említették, ahogyan a fertőtlenítést és a kézmosási lehetőséget is. Mások szerint a megfelelő közösségi programokkal lehet elérni, hogy újra vonzóak legyenek a parkok és terek, ugyanakkor többen írták, hogy szükség lenne 
arra, hogy a padokat megfelelő távolságra helyezzék el egymástól, annak érdekében, hogy a védőtávolság biztosított legyen járványveszély esetén is.

A felmérés utolsó kérdése arra vonatkozott, hogy a járvány elmúlását követően mire kell majd figyelniük a helyi önkormányzatoknak a terek és parkok kialakítása és fejlesztése során. A kérdőív kitöltői válaszuk jelentős részében a tisztaságot, a higiéniát, a rendszeres karbantartást, illemhelyek kialakítását és a növények gondozását emelték ki. Sokan írták azonban ennél a kérdésnél is, hogy elegendő mennyiségű szemetesre lenne szükség a közösségi tereken, valamint az árnyékolásra a parkokban. Többen megfogalmazták azt az igényüket is, hogy a parkokban egyértelműen különüljenek el egymástól a funkciók, így például a sportpályán edzők ne zavarják a játszóteret használó gyerekeket és szülőket. Voltak, akik azt nehezményezték, hogy nincs egy tér vagy park létrehozása, fejlesztése során megfelelő párbeszéd a helyi önkormányzatok és a lakosság között, ilyen esetekben szükség lenne a közösségi tervezésre. Többek a biztonságot emelték ki, ami köztéri kamerák elhelyezésével lenne megoldható, valamint azt, hogy ezek a közterek minden korosztály számára legyenek vonzóak. Szükség lenne továbbá több növényzet telepítésére, valamint a kutyás területek elkülönítésére és a „kutyazacskók” kihelyezésére.

\section{Összegzés}

Az online felmérés eredményéből egyértelműen kiderült, hogy a válaszadók jelentős része betartotta a kijárási korlátozást, és nem kereste fel a hozzá közi tereket vagy parkokat. Ugyanakkor a válaszadók 46\%-a különböző intenzitással ugyan, de a korlátozások ellenére továbbra is látogatta a közösségi tereket. Mindezt pedig elsősorban azzal indokolták, hogy a sportlétesítmények bezárása miatt ezek a terek jelentették a legjobb alternatívát a napi testmozgásra. Az otthoni munkavégzés bevezetésével többen úgy tudták alakítani napi teendőiket, hogy gyakrabban sikerült meglátogatniuk a közeli parkokat vagy tereket. A válaszadók elsősorban sétálni szeretnek ezeken a helyeken, úgy a járvány kitörése előtti, alatti, valamint a jövőbeni időszakban. A közterek a pihenés és a kikapcsolódás, valamint a játszótér használata, a sportolás, végül pedig a társas kapcsolatok ápolása szempontjából is fontosak. A járvány kitörése utáni időszakban ezeknek a tevékenységeknek a népszerűsége természetesen visszaesett, ami különösen a játszóterek használatát, és a társas kapcsolatok ápolását érintette.

A felmérés alapján az emberek számára különösen fontosak a környezetükben található terek és parkok. A 2012-ben végzett kutatásommal összehasonlítva a jelenlegi felmérésben sokkal markánsabban megjelent a közösségi terek tisztán tartása, gondozása, valamint a több növényzet iránti igény. A higiénia kiemelt fontossága feltehetően a koronavírus-járványtól való félelem- 
nek köszönhető, ugyanakkor többen éppen a járvány ideje alatt tudták felkeresni a hozzájuk közeli tereket, ők e tapasztalatok alapján fogalmazták meg véleményüket.

Az adatokból rövid távon azt láthatjuk, hogy a járvány nem befolyásolta jelentős mértékben a közösségi terek ritkább vagy sűrübb látogatását, arra ugyanakkor már hatással volt, hogy az emberek mikor tervezik újra igénybe venni a kedvenc parkjukat vagy terüket a járvány elmúltával.

Arra a kérdésre, hogy a koronavírus-járvány hosszútávon milyen hatást gyakorolt a közösségi terek használatára, csak további kutatások tudnak választ adni. Ezek ugyanis segíthetnek pontosan feltárni, hogy hasonló világjárvány esetén az önkormányzatoknak milyen változásokkal kell számolniuk közterületeik használatát illetően, s ezért segíthetnek abban, hogy a települések a jövőben is élhetőek és fenntarthatóak maradjanak.

\section{Irodalom}

Anguluri, R., Narayanan, P. (2017): Role of green space in urban planning: Outlook towards smart cities. Urban Forestry \& Urban Greening, 25., 58-65.

Gehl J. (2014): Élhető városok. TERC Kereskedelmi és Szolgáltató Kft., Budapest

Jóna L. (2016): Idóben és rendeltetésben korlátozott városi terek problémáinak vizsgálata. Doktori értekezés. Széchenyi István Egyetem Multidiszciplináris Műszaki Doktori Iskola, Győr https:www.rkk.hu/rkk/publications/phd/jona_ertekezes.pdf

Madden, K. (2008): Hogyan varázsoljunk újjá egy közteret? Kézikönyv jól múködő közösségi terek létrehozásához. Ökotárs Alapítvány, Budapest

Thompson, C. W. (2002): Urban open space in the 21st century. Landscape and Urban Planning, 60., 59-72.

71/2020. (III. 27.) Korm. rendelet a kijárási korlátozásról 